\title{
Environmental Learning Based on Higher Order Thinking Skills: A Needs Assessment
}

\author{
IImi Zajuli Ichsan ${ }^{1, a^{*}}$, Diana Vivanti Sigit ${ }^{1, b}$, Mieke Miarsyah ${ }^{1, c}$ \\ ${ }^{1}$ Department of Biology Education, Faculty of Mathematics and Natural Sciences, Universitas Negeri Jakarta, Jakarta, Indonesia \\ a ilmizajuli95@gmail.com; b dianav@unj.ac.id; c mmiarsyah@unj.ac.id \\ ${ }^{*}$ Corresponding Author
}

How to Cite: Ichsan, I. Z., Sigit, D. V., \& Miarsyah, M. (2019). Environmental Learning Based on Higher Order Thinking Skills: A Needs Assessment. International Journal for Educational and Vocational Studies, 1(1), 21-24. DOI: https://doi.org/10.29103/ijevs.v1i1.1389

\section{ARTICLE HISTORY}

Received: 10 March 2019

Revised: 16 April 2019

Accepted: 28 April 2019

\section{KEYWORDS}

Environmental learning

Higher Order Thinking Skills

Need assessment

\begin{abstract}
Environmental learning at the school and university levels, often still uses conventional learning. This is a problem, considering the ability of students' Higher Order Thinking Skills (HOTS) is very necessary for the 21st century. The purpose of this study is to do need assessment on learning media, teaching materials, learning materials, worksheets, and learning evaluations used in the learning environment in schools and universities. The study was conducted from November 2017 - January 2019 at several schools in Bekasi and one university in Jakarta. The research method used is descriptive method with data collection techniques using observation and interviews. The results showed that media learning, teaching materials, learning materials, students worksheets, and learning evaluations at various levels were not all based on HOTS. HOTS-based learning has been applied at the university level and senior high school but is still rarely used. This is due to the lack of development in environmental learning. The conclusion of this study is that environmental learning is not all HOTS-based.
\end{abstract}

\section{INTRODUCTION}

Environmental problems around us are often ignored and not discussed in learning. These problems are often encountered by students around their home environment such as floods, water pollution, recycling problems, and other problems. Unfortunately, in environmental learning, it is often not discussed in detail the environmental problems that occur in the classroom (Fisher-Maltese \& Zimmerman, 2015; Mustam \& Daniel, 2016).

The consequences of not discussing environmental issues in learning result in students not understanding in depth the real problems. This is exacerbated by the low ability of students' Higher order thinking skills. HOTS is very necessary for environmental learning because environmental problems are complex problems so students need the ability to analyze, evaluate, and create (Anderson et al., 2001; Lee \& Lai, 2017; Tajudin \& Chinnappan, 2016; Vidergor, 2018).

Students with high HOTS will be critical students of an environmental problem and can do analysis, and create solutions. The problem is that various media learning, teaching materials, learning materials, students worksheets, and learning evaluation still use conventional ones. Even though the use of media learning, teaching materials, learning materials, worksheets, and HOTS-based learning evaluations are needed in 21st-century learning (Quieng, Lim, \& Lucas, 2015; Sharif \& Cho, 2015; Talmi, Hazzan, \& Katz, 2018).

Previous research often only developed various HOTS-based learning tools but did not need the needs assessment first. Although indeed there are many results of previous studies which show that the development has succeeded in influencing HOTS students (Hugerat \& Kortam, 2014; Murphy, Bianchi, McCullagh, \& Kerr, 2013; Saido, Siraj, DeWitt, \& Al-Amedy, 2018). But still, need more comprehensive need assessment from various levels of education. Therefore, the novelty offered in this research is a comprehensive need assessment from elementary school to university levels which is reviewed in terms of HOTS. Assessment needs in terms of HOTS in environmental learning are a novelty because not many have done it and been published. 
Based on these problems, needs assessment needs to be done descriptively about the conditions of learning in schools and universities in terms of HOTS. The purpose of this study is to do need assessment on learning media, teaching materials, learning materials, worksheets, and learning evaluations used in environmental learning at the school to university level.

\section{METHODS}

This research was conducted in November 2017 - January 2019. Located in State Elementary School 02 Jatimulya of South Tambun, State Junior High School 1 of South Tambun, Senior High School 5 of South Tambun, and State University of Jakarta (Universitas Negeri Jakarta). All schools are located in Bekasi, West Java, Indonesia. The university is located in the capital of Jakarta, Indonesia. HOTS used as a reference in this study is by what was stated by Anderson et al. (2001) namely analyze, evaluate, and create.

The research method used is descriptive method with data collection techniques through interviews and direct observation. There are 10 aspects observed in this study (1) Learning in the curriculum of 2013 (2) Use of HOT-based Learning media in environmental learning (3) Use of the HOTS-based Teaching materials in environmental learning (4) Use of HOT-based Learning materials in environmental learning (5) Use of HOTS-based students in environmental learning worksheets (6) Use of HOTS-based learning evaluations in environmental learning (7) Use websites, android applications, e-books, and other modern media in environmental learning (8) Conventional learning media / teaching materials in environmental learning (9) Discuss environmental issues such as: green consumerism, climate change,eco-labels, global warming and other environmental current issues, etc. (10) Use of enrichment books/module to increase student knowledge on environmental learning.

The instruments used in this study were observation sheets and also interviewed sheets. The results of the observations are then written and described in table form. If the observed aspects have been carried out routinely at each meeting, the information given is 'already'. If it has been implemented but the implementation is only carried out 1-2 times and is not routine, it will be written 'rarely used'. If it has not been implemented, it will be written 'not yet'.

\section{RESULTS AND DISCUSSION}

The results of the research conducted are summarized in table 1 below. The results show that in general the learning at elementary school and Junior High School levels still do not carry out HOTS-based learning. While at a higher level, senior high school is starting to be used HOTS-based learning but it is still rare.

Table 1. Results of observations and interviews of HOTS-based learning

\begin{tabular}{|c|c|c|c|c|c|}
\hline No & Aspects & $\begin{array}{l}\text { Elementary } \\
\text { School }\end{array}$ & $\begin{array}{l}\text { Junior High } \\
\text { School }\end{array}$ & Senior High School & University \\
\hline 1 & $\begin{array}{l}\text { Learning according to the curriculum of } 2013 \text { (kurtilas) in } \\
\text { Indonesia }\end{array}$ & already & already & already & already \\
\hline 2 & Use of HOTS-based Learning media in environmental learning & not yet & not yet & rarely used & rarely used \\
\hline 3 & $\begin{array}{l}\text { Use of HOTS-based Teaching materials in environmental } \\
\text { learning }\end{array}$ & not yet & not yet & rarely used & rarely used \\
\hline 4 & $\begin{array}{l}\text { Use of HOTS-based Learning materials in environmental } \\
\text { learning }\end{array}$ & not yet & not yet & rarely used & rarely used \\
\hline 5 & $\begin{array}{l}\text { Use of HOTS-based students worksheet in environmental } \\
\text { learning }\end{array}$ & rarely used & rarely used & rarely used & rarely used \\
\hline 6 & $\begin{array}{l}\text { Use of HOTS-based learning evaluation in environmental } \\
\text { learning }\end{array}$ & not yet & not yet & rarely used & rarely used \\
\hline 7 & $\begin{array}{l}\text { Use website, android application, e-book, and other modern } \\
\text { media in environmental learning }\end{array}$ & not yet & not yet & rarely used & rarely used \\
\hline 8 & $\begin{array}{l}\text { Conventional learning media/teaching materials in } \\
\text { environmental learning }\end{array}$ & Textbook & Textbook & Textbook and ppt & Textbook and ppt \\
\hline 9 & $\begin{array}{l}\text { Discuss current environmental issues such as green } \\
\text { consumerism, climate change, eco-label, global warming, and } \\
\text { another current environmental issue, etc. }\end{array}$ & not yet & not yet & rarely & rarely \\
\hline 10 & $\begin{array}{l}\text { Use of enrichment books/module to increase student } \\
\text { knowledge on environmental learning }\end{array}$ & not yet & not yet & not yet & not yet \\
\hline
\end{tabular}

Note: Ppt (powerpoint)

In environmental learning at the elementary school level, Junior High School, Senior High School, and university all have implemented the 2013 current curriculum (Kurtilas). This can be seen from the application of learning strategies that have been used to direct students to student-centered. Although not entirely, but from the results of observations in general, there is a 2013 curriculum that applies in Indonesia. Curriculum has advantages in terms of student abilities based on the scientific method approach. The application of the curriculum will have an impact on increasing HOTS students. That is because students are accustomed to thinking and analyzing problems and giving judgments and creating solutions (Husamah, Fatmawati, \& Setyawan, 2018; Narayanan \& Adithan, 2015; Ritter \& Mostert, 2017; Teimourtash \& YazdaniMoghaddam, 2017). 
Another interesting thing from the results of this study is that media learning, teaching materials, learning materials, worksheets, and learning evaluations used in environmental learning are generally not HOTS-based. Especially for elementary school and Junior High School levels. While for senior level High schools and universities, it has been used but with a frequency of use that can be categorized as rare. This can happen because, at the elementary school and junior high school levels, environmental learning gets a very small portion of science learning. Even sometimes for some subtopics, the teacher does not teach and even skip it. This is something that is wrong, considering HOTS-based environmental learning is very important for students because students after learning it can have a high HOTS (Afflerbach, Cho, \& Kim, 2015; Bojey, Hui, \& Campbell, 2014; Dubas \& Toledo, 2016; Koutsoukos, Fragoulis, \& Valkanos, 2015; Tanujaya, Mumu, \& Margono, 2017).

In addition to the problem of very small portions, some teachers also think that environmental learning is enough to remember and memorize the material in the textbook. This is one reason teachers are reluctant not to carry out further development. Even though the development of HOTS-based learning is very important, if learning only uses conventional media, then students' knowledge will be very superficial to a current environmental problem such as green consumerism, climate change, eco-labels, global warming, and other environmental issues. Though to be able to contribute to the environment, these students must have strong analytical skills and that is reflected in HOTS (FitzPatrick \& Schulz, 2015; Hwang, Lai, Liang, Chu, \& Tsai, 2018; Roderer \& Roebers, 2014; Vidergor, 2018; Yee et al., 2015).

Development of media learning, teaching materials, learning materials, students worksheets, and learning evaluations can be done for various levels (Alias, DeWitt, \& Siraj, 2013; Hamden \& Low, 2015; Said \& Syarif, 2016; Sriwongchai, Jantharajit, \& Chookhampaeng, 2015; Yang, Lee, Hong, \& Lin, 2016). Even though senior high school and university levels have been used, their use is still rarely used. HOTS aspects can be inserted in media learning, teaching materials, learning materials, worksheet students, and learning evaluation. For example, if we are going to develop teaching materials, it can be inserted an environmental problem that must be solved by students in the teaching material. Students will be aroused to think and will slowly increase HOTS. In addition to the development of worksheet students, a project can also be inserted that trains students to create something in order to solve environmental problems. This is in accordance with HOTS, namely create, ie students are required to make something (Camacho \& Legare, 2015; Hidayati \& Wuryandari, 2012; Yavich \& Starichenko, 2017; Yusnaeni, Corebima, Susilo, \& Zubaidah, 2017).

Efforts can be made in addition to developing and using websites, android applications, e-books, actually an enrichment can be done. The function of this enrichment is certainly to provide more information to students about current issues of environmental problems in the world. This can be done as a form to increase HOTS. That is because the current issue of the environment can be used as material for study and analysis for students (Choudri et al., 2017; Dangelico, Pujari, \& Pontrandolfo, 2017; Lekakos, Vlachos, \& Koritos, 2014). Students can be trained to analyze problems that exist in the world and try to make a research design to solve certain problems around them.

\section{CONCLUSION}

Based on the results of the study, it can be concluded that media learning, teaching materials, learning materials, worksheet students, and learning evaluations used are still not all HOTS-based. That is because the teacher only teaches students based on material from the textbook. Even though teachers can enrich to increase students' knowledge, so HOTS students can increase.

\section{REFERENCES}

Afflerbach, P., Cho, B. Y., \& Kim, J. Y. (2015). Conceptualizing and Assessing Higher-Order Thinking in Reading. Theory into Practice, 54(3), 203-212. https://doi.org/10.1080/00405841.2015.1044367

Alias, N., DeWitt, D., \& Siraj, S. (2013). Design and Development of Webquest for Physics Module by Employing Isman Instructional Design Model. Procedia - Social and Behavioral Sciences, 103, 273-280. https://doi.org/10.1016/j.sbspro.2013.10.335

Anderson, L. W., Krathwohl, D. R., Airiasian, W., Cruikshank, K. A., Mayer, R. E., \& Pintrich, P. R. (2001). A taxonomy for learning, teaching and assessing: A revision of Bloom's Taxonomy of educational outcomes: Complete edition. New York: Longman.

Bojey, M., Hui, B., \& Campbell, R. (2014). Engaging higher order thinking skills with a personalized physics tutoring system. Lecture Notes in Computer Science (Including Subseries Lecture Notes in Artificial Intelligence and Lecture Notes in Bioinformatics), 8474 LNCS, 613-614. https://doi.org/10.1007/978-3-319-07221-0_78

Camacho, D. J., \& Legare, J. M. (2015). Opportunities to Create Active Learning Techniques in the Classroom. Journal of Instructional Research, 4, 38-45.

Choudri, B. S., Baawain, M., Al-Zeidi, K., Al-Nofli, H., Al-Busaidi, R., \& Al-Fazari, K. (2017). Citizen perception on environmental responsibility of the corporate sector in rural areas. Environment, Development and Sustainability, 19(6), 2565-2576. https://doi.org/10.1007/s10668-016-9855-y

Dangelico, R. M., Pujari, D., \& Pontrandolfo, P. (2017). Green Product Innovation in Manufacturing Firms: A Sustainability-Oriented Dynamic Capability Perspective. Business Strategy and the Environment, 26(4), 490-506. https://doi.org/10.1002/bse.1932

Dubas, J. M., \& Toledo, S. A. (2016). Taking higher order thinking seriously: Using Marzano's taxonomy in the economics classroom. International Review of Economics Education, 21, 12-20. https://doi.org/10.1016/j.iree.2015.10.005

Fisher-Maltese, C., \& Zimmerman, T. D. (2015). A garden-based approach to teaching life science produces shifts in students' attitudes toward the environment. International Journal of Environmental and Science Education, 10(1), 51-66. https://doi.org/10.12973/ijese.2015.230a

FitzPatrick, B., \& Schulz, H. (2015). Do Curriculum Outcomes and Assessment Activities in Science Encourage Higher Order Thinking? Canadian Journal of Science, Mathematics and Technology Education, 15(2), 136-154. https://doi.org/10.1080/14926156.2015.1014074 
Hamden, M., \& Low, K. C. P. (2015). Ecotourism development in Brunei Darussalam. Transnational Corporations Review, 6(3), 248-272. https://doi.org/10.5148/tncr.2014.6304

Hidayati, N., \& Wuryandari, A. I. (2012). Media Design for Learning Indonesian in Junior High School Level. Procedia - Social and Behavioral Sciences, 67, 490-499. https://doi.org/10.1016/j.sbspro.2012.11.354

Hugerat, M., \& Kortam, N. (2014). Improving higher order thinking skills among freshmen by teaching science through inquiry. Eurasia Journal of Mathematics, Science and Technology Education, 10(5), 447-454. https://doi.org/10.12973/eurasia.2014.1107a

Husamah, H., Fatmawati, D., \& Setyawan, D. (2018). OIDDE Learning Model: Improving Higher Order Thinking Skills of Biology Teacher Candidates. Interntaional Journal of Instruction, 11(2), 249-264.

Hwang, G.-J., Lai, C.-L., Liang, J.-C., Chu, H.-C., \& Tsai, C.-C. (2018). A long-term experiment to investigate the relationships between high school students' perceptions of mobile learning and peer interaction and higher-order thinking tendencies. Educational Technology Research and Development, 66(1), 75-93. https://doi.org/10.1007/s11423-017-9540-3

Koutsoukos, M., Fragoulis, I., \& Valkanos, E. (2015). Connection of environmental education with application of experiential teaching methods: A case study from Greece. International Education Studies, 8(4), 23-28. https://doi.org/10.5539/ies.v8n4p23

Lee, K., \& Lai, Y. (2017). Facilitating higher-order thinking with the flipped classroom model: a student teacher's experience in a Hong Kong secondary school. Research and Practice in Technology Enhanced Learning, 12(1). https://doi.org/10.1186/s41039-017-0048-6

Lekakos, G., Vlachos, P., \& Koritos, C. (2014). Green is good but is usability better? Consumer reactions to environmental initiatives in e-banking services. Ethics and Information Technology, 16(2), 103-117. https://doi.org/10.1007/s10676-014-9337-6

Murphy, C., Bianchi, L., McCullagh, J., \& Kerr, K. (2013). Scaling up higher order thinking skills and personal capabilities in primary science: Theory-into-policy-into-practice. Thinking Skills and Creativity, 10, 173-188. https://doi.org/10.1016/j.tsc.2013.06.005

Mustam, B., \& Daniel, E. S. (2016). Informal and Formal Environmental Education Infusion: Actions of Malaysian Teachers and Parents among Students in a Polluted Area. Malaysian Online Journal of Educational Sciences, $\quad 4(1), \quad 9-20 . \quad$ Retrieved from http://www.moj-es.net/frontend/articles/pdf/v04i01/v04-i01-01.pdf

Narayanan, S., \& Adithan, M. (2015). Analysis of Question Papers in Engineering Courses with Respect to HOTs (Higher Order Thinking Skills). American Journal of Engineering Education, 6(1), 1-10.

Quieng, M. C., Lim, P. P., \& Lucas, M. R. D. (2015). 21st Century-based Soft Skills: Spotlight on Non-cognitive Skills in a Cognitive-laden Dentistry Program. European Journal of Contemporary Education, 11(1), 72-81. https://doi.org/10.13187/ejced.2015.11.72

Ritter, S. M., \& Mostert, N. (2017). Enhancement of Creative Thinking Skills Using a Cognitive-Based Creativity Training. Journal of Cognitive Enhancement, 1(3), 243-253. https://doi.org/10.1007/s41465-016-0002-3

Roderer, T., \& Roebers, C. M. (2014). Can you see me thinking (about my answers)? Using eye-tracking to illuminate developmental differences in monitoring and control skills and their relation to performance. Metacognition and Learning, 9(1), 1-23. https://doi.org/10.1007/s11409-013-9109-4

Said, A., \& Syarif, E. (2016). The Development of Online Tutorial Program Design Using Problem-Based Learning in Open Distance Learning System. Journal of Education and Practice, 7(18), 222-229.

Saido, G. A. M., Siraj, S., DeWitt, D., \& Al-Amedy, O. S. (2018). Development of an instructional model for higher order thinking in science among secondary school students: a fuzzy Delphi approach.
International Journal of Science Education, 40(8), 847-866. https://doi.org/10.1080/09500693.2018.1452307

Sharif, A., \& Cho, S. (2015). 21st-Century Instructional Designers: Bridging the Perceptual Gaps between Identity, Practice, Impact and Professional Development. RUSC. Universities and Knowledge Society Journal, 12(3), 72-85. https://doi.org/10.7238/rusc.v12i3.2176

Sriwongchai, A., Jantharajit, N., \& Chookhampaeng, S. (2015). Developing the Mathematics Learning Management Model for Improving Creative Thinking In Thailand. International Education Studies, 8(11), 77-87. https://doi.org/10.5539/ies.v8n11p77

Tajudin, N. M., \& Chinnappan, M. (2016). The Link between Higher Order Thinking Skills, Representation and Concepts in Enhancing TIMSS Tasks. International Journal of Instruction, 9(2), 199-214. https://doi.org/10.12973/iji.2016.9214a

Talmi, I., Hazzan, O., \& Katz, R. (2018). Intrinsic Motivation and 21st-Century Skills in an Undergraduate Engineering Project: The Formula Student Project. Higher Education Studies, 8(4), 46. https://doi.org/10.5539/hes.v8n4p46

Tanujaya, B., Mumu, J., \& Margono, G. (2017). The Relationship between Higher Order Thinking Skills and Academic Performance of Student in Mathematics Instruction. International Education Studies, 10(11), 78-85. https://doi.org/10.5539/ies.v10n11p78

Teimourtash, M., \& YazdaniMoghaddam, M. (2017). On the Plausibility of Bloom's Higher Order Thinking Strategies on Learner Autonomy: The Paradigm Shift. Asian-Pacific Journal of Second and Foreign Language Education, 2(1), 14. https://doi.org/10.1186/s40862-017-0037-8

Vidergor, H. E. (2018). Effectiveness of the multidimensional curriculum model in developing higher-order thinking skills in elementary and secondary students. Curriculum Journal, 29(1), 95-115. https://doi.org/10.1080/09585176.2017.1318771

Yang, K. K., Lee, L., Hong, Z. R., \& Lin, H. S. (2016). Investigation of effective strategies for developing creative science thinking. International Journal of Science Education, 38(13), 2133-2151. https://doi.org/10.1080/09500693.2016.1230685

Yavich, R., \& Starichenko, B. (2017). Design of Education Methods in a Virtual Environment. Journal of Education and Training Studies, 5(9), 176. https://doi.org/10.11114/jets.v5i9.2613

Yee, M. H., Yunos, J. M., Othman, W., Hassan, R., Tee, T. K., \& Mohamad, M. M. (2015). Disparity of Learning Styles and Higher Order Thinking Skills among Technical Students. Procedia - Social and Behavioral Sciences, 204(November 2014), 143-152. https://doi.org/10.1016/j.sbspro.2015.08.127

Yusnaeni, Y., Corebima, A. D., Susilo, H., \& Zubaidah, S. (2017). Creative Thinking of Low Academic Student Undergoing Search Solve Create and Share Learning Integrated with Metacognitive Strategy. International Journal of Instruction, 10(2), 245-262. https://doi.org/10.1016/j.spinee.2011.10.010 